Syahron. et.al. Memotivasi Pembelajaran Bahasa Inggris Melalui Metode Belajar Ctl Di Mas Tahfizil Qur'an Dan Mts Hifzhil Qur'an Medan Sumatera Utara

\title{
MEMOTIVASI PEMBELAJARAN BAHASA INGGRIS MELALUI METODE BELAJAR CTL DI MAS TAHFIZIL QUR'AN DAN MTs HIFZHIL QUR'AN MEDAN SUMATERA UTARA
}

\author{
Syahron Lubis ${ }^{1)}$, Muhizar Muchtar ${ }^{2)}$, Rahmadsyah Rangkuti ${ }^{3)}$ \\ ${ }^{1)}$ Program Studi Sastra Inggris, Fakultas Ilmu Budaya, Universitas Sumatera Utara, Medan Indonesia \\ Email: ronlubis@gmail.com \\ ${ }^{2)}$ Program Studi Sastra Inggris, Fakultas Ilmu Budaya, Universitas Sumatera Utara, Medan Indonesia \\ Email:muhizarm@yahoo.com \\ ${ }^{3)}$ Program Studi Sastra Inggris, Fakultas Ilmu Budaya, Universitas Sumatera Utara, Medan Indonesia \\ Email: syahkuti@gmail.com
}

\begin{abstract}
Abstrak
Dalam sebuah pembelajaran tentunya membutuhkan sebuah metode yang tepat untuk mendapatkan hasil yang maksimal. Pencapaian tujuan dalam pengabdian masyarakat berupa penyelenggaraan kegiatan pelatihan bahasa Inggris adalah peningkatan motivasi atau kemauan diri, pemahaman dan kemampuan siswa/i dalam belajar sebuah bahasa. Adapun tujuan penelitian ini adalah untuk mengetahui bagaimanakah kemampuan siswa dalam mempelajari tatabahasa Inggris dengann menggunakan metode CTL dan untuk mengetahui bagaimanakah pengaruh metode tersebut terhadap semangat proses belajar mengajar siswa. Jenis penelitian yang digunakan untuk mengetahui hasil dari tujuan penelitian ini peneliti menggunakan pendekatan kulaitatif berupa penelitian lapangan. Kesimpulan yang diperoleh setelah dilakukannya penelitian bahwa: 1) Pelatihan Memotivasi Pembelajaran Bahasa Inggris Melalui Metode Belajar CTL Di MAS Tahfizil Qur'andanMTs Hifzhil Qur'an Sumatera Utara telah dilakukan dan hasilnya sangat memuaskan. 2)Metode belajar Contextual Teaching and Learning (CTL) yang telah di terapkan kepada siswa MAS Tahfizil Qur'andanMTs Hifzhil Qur'an Sumatera Utara memberikan hasil yang signifikan dimana para siswa termotivasi dan dapat mengikuti metode tersebut sehingga pemahaman terhadap struktur grammar kalimat langsung dan kalimat tidak langsung dipahami secara menyeluruh dalam waktu yang relative singkat. 3) Kemampuan siswa dalam memahami grammar setelah diajarkan dengan menggunakan metode belajar CTL meningkat dalam persentase 75\% hasil memuaskan di MAS Tahfizil Qur'an dan 70\% hasil memuaskan di MTs Hifzhil Qur'an Sumatera Utara. 4) Antusiasme dari para siswa terhadap metode yang mereka anggap baru ini tergolong baru.
\end{abstract}

Kata Kunci: Memotivasi, Metode CTL, Pembelajaran

\section{PENDAHULUAN}

Di negara Indonesia Bahasa Inggris merupakan bahasa asing yang utama dan dianggap sebagai mata kuliah wajib yang harus diajarkan mulai dari tingkat Sekolah Dasar hingga Universitas. Disamping itu bahasa Inggris juga merupakan bahasa Internasional yang dapat membantu orang untuk berinteraksi, berkomunikasi dan berbagi informasi dengan orang lain di berbagai belahan dunia bahkan bukan tidak memungkinkan bagi setiap orang untuk bisa mengelilingi dunia dan juga bisa berkomunikasi dengan orang lain di seluruh dunia jika seseorang menguasai bahasa Inggris dengan baik. Olehkarena itu,
Kemampuan berbahasa Inggris sangat penting bagi setiap orang. Ditambah lagi, sebagian besar buku ilmiah tentang penemuan baru banyak dituliskan dan dicetak dalam bahasa Inggris.

Bertalian dengan bahasa Inggris sebagai bahasa internasional, memahami struktur bahasa (grammar) memiliki peran yang sangat penting dalam memahami sebuah bahasa bagi semua profesi dari siswa hingga pekerja professional. Untuk mengikuti kemajuan perkembangan ilmu pengetahuan dan teknologi pada tiap - tiap disiplin ilmu, para ilmuan dan peneliti perlu memahami struktur bahasa (grammar) untuk memahami jurnal - jurnal ilmiah 
dalam bahasa Inggris. Sumber - sumber referensi yang lain juga sebagian besar berbahasa Inggris. Bagi mereka yang mempelajari bahasa Inggris sebagai bahasa kedua atau bahasa asing, karya - karya sastra dalam bahasa Inggris merupakan sarana yang membuka kazanah pengetahuan mereka tentang sastra dan budaya penutur aslinya.

Namun sangat disayangkan, kemampuan berbahasa Inggris, khususnya dibidang struktur bahasa (grammar) yang bersifat akademis (tatabahasa), tidak sepenuhnya dimiliki oleh siswa MAS Tahfizil Qur'an Dan MTS Hifzhil Qur'an Medan Sumatera Utara.Bahkan kepala sekolah mengakui kurangnya motivasi pembelajaran bahasa Inggris bagi siswa khususnya melalui metode pembelajaran yang berbasis kompetensi yang bisa mengikuti perkembangan zaman.

Meskipun jumlah siswa yang lulus pada ujian nasional cukup menggembirakan, namun jumlah nilai kelululusan siswa sangat rendah, ditambahlagi siswa yang mengikuti dan lulus ujian masuk perguruan tinggi negeri sangat rendah. Survei awal yang dilakukan oleh tim dengan menanyakan kepada siswa alasan mengapa mereka enggan mengikuti ujian masuk PTN dijawab dengan keengganan dan kekhawatiran mereka untuk menghadapi soal ujian khususnya yang berkaitan dengan bahasa Inggris, meskipun keinginan untuk bisa kuliah di PTN sangat besar. Hal ini dikarenakan adanya jenis soal yang berbentuk membaca teks dan tatabahasa dimana siswa kemudian mengakui bahwa kemampuan mereka untuk dapat memahami teks dan tatabahasa dengan cepat sesuai dengan waktu ujian yang disediakan sangatlah lemah.

Lokasi sekolah ini di MAS Tahfizil Qur'an Dan MTS Hifzhil Qur'an Medan Sumatera Utara.cukup refresentatif sehingga membuat sekolah tersebut menjadi sekolah favorit bagi remaja di kota Medan dan juga dari luar kota Medan tersebut. Ditambah lagi sekolah tersebut merupakan sekolah swasta yang merupakan sekolah yang sangat dipercayakan orang tua agar anaknya bisa menimba ilmu dengan baik.Disamping itu orangtua juga sangat mengharapkan dengan menyekolahkan anaknya di sekolah tersebut bisalah nantinya anaknya menimba ilmu agama dan melanjutkan studi ke jenjang perguruan tinggi atau bisa kerja di salah satu instansi pemerintah sebagai PNS ataupun isntansi swasta lainnya. Ini menjadi alasan yang mendasari mengapa tim dari Departemen Sastra Inggris memilih sekolah ini untuk dijadikan tempat untuk meningkatkan motivasi pembelajaran bahasa Inggris khususnya melalui metode pembelajaran yang berbasis kompetensi yang bisa mengikuti perkembangan zaman, bertujuan untuk membantu meningkatkan motivasi siswa dalam pembelajaran bahasa Inggris dan juga untuk menghadapi ujian masuk perguruan tinggi.

Berdasarkan pengamatan timpeneliti di MAS Tahfizil Qur'an Dan MTS Hifzhil Qur'an Medan Sumatera Utara. Tim menemukan bahwa pengajaran tata bahasa jauh dari apa yang diharapkan kurikulum. Hal itu bisa dilihat saat para siswa diminta menuliskan kalimat setelah guru menjelaskan aturan tata bahasa seperti mengubah kalimat langsung menjadi kalimat tidak langsung atau sebaliknya, ternyata masih banyak para siswa tidak dapat melakukannya dengan benar.

Banyak juga siswa yang mengatakan kalau mereka cukup kesulitan untuk memahami bentuk struktur kalimat tersebut. Sehingga hal tersebut membuat mereka menjadi kurang termotivasi untuk belajar bahasa Inggris dengan baik. Olehkarena itu, bisa disimpulkan bahwa dengan jelas siswa memiliki motivasi belajar bahasa Inggris yang sangat rendah sekali terutama tentang tata bahasa, khususnya mengenai pemahaman kalimat langsung dan kalimat tidak langsung. Padahal kita tahu sendiri bahwa materi tata bahasa kalimat tersebut selalu hadir baik dalam ujian nasional yang dihadapi oleh siswa setiap tahunnya. Demikian juga dalam soal - soal ujian masuk ke perguruan tinggi negeri seperti 
Syahron. et.al. Memotivasi Pembelajaran Bahasa Inggris Melalui Metode Belajar Ctl Di Mas Tahfizil Qur'an Dan Mts Hifzhil Qur'an Medan Sumatera Utara

SBMPTN, kita selalu di hadapkan dengan berbagai soal dalam bentuk tata bahasa begitu juga dengan kalimat langsung dan kalimat tidak langsung. Bahkan dalam sebuah percakapan bahasa Inggris kita selalu menggunakan kalimat yang bernuansa kalimat langsung dan kalimat tidak langsung.

Tim peneliti juga menemukan bahwa banyak sekali pembelajaran bahasa Inggris khususnya yang berbau grammar atau tata bahasa, pengajarannya dilakukan dengan metode ceramah atau penjelasan oleh guru, pembelajaran yang monoton atau hanya satu arah saja, sehingga membuat aktivitas proses belajar mengajar siswa menjadi mudah bosan dan tidak termotivasi sama sekali. Pada hal dalam sebuah pembelajaran, ada sebenarnya sebuahmetode pembelajaran yang baik yang harus diketahui oleh seorang guru sehingga hal - hal tersebut bisa di hindari dan di atasi dengan baik. Salah satu metode yang dimaksudkan tim penulis adalah dengan menggunakan metode Contextual Teaching and Learning (CTL).Contextual Teaching and Learning (CTL) adalah metode yang menekankan pada proses keterlibatan siswa untuk mengetahui materi dan mengaitkannya dengan kondisi sebenarnya. Oleh karena itu mereka bisa menerapkan apa yang mereka dapatkan dalam hidup mereka.

Salah satu komponen dalam CTL adalah belajar berkelompok. Peneliti menganggap bahwa pembelajaran berkelompok merupakan strategi yang tepat dalam pengajaran berbicara langsung dan tidak langsung, karena dalam pembelajaran berkelompok siswa dapat memecahkan masalah dengan teman mereka di kelompoknya. Apalagi guru adalah sebagai perancang dalam proses belajar mengajar yang bisa mengarahkan mereka dengan baik. Sehingga siswa akan merasa enjoy dalam belajar struktur tatabahasa tersebut dan bisa membuat mereka mudah memahaminya dan menggunakannya dalam sebuah kalimat terlebih - lebih dalam sebuah percakapan yang sederhana.
Berdasarkan identifikasi atau penjelasan di atas, maka dari itu peneliti memutuskan untuk menentukan penelitiannya untuk membahas mengenai penerapan metode Pembelajaran dan pengajaran Kontekstual (CTL) dalam pengajaran kalimat Langsung dan tidak Langsung.Oleh karena itu, peneliti ingin melakukan penelitian yang berjudul "Memotivasi Pembelajaran Bahasa Inggris Melalui Metode Belajar CTL di MAS Tahfizil Qur'an Dan MTS Hifzhil Qur'an Medan Sumatera Utara."

Setelah pengabdian ini dilaksanakan, tim berharap agar jumlah siswa yang termotivasi dalam pembelajaran bahasa Inggris melalui sebuah metode dapat meningkat secara signifikan dan berkesinambungan.

\section{PERUMUSAN MASALAH}

Dalam pengabdian ini, yang menjadi rumusan masalahnya adalah:

1. Bagaimanakah kemampuan pemahaman siswa dalam memahami tatabahasa Inggris 'direct and indirect speech' MAS Tahfizil Qur'an Dan MTS Hifzhil Qur'an Medan Sumatera Utaramelalui sebuah metode belajar CTL?

2. Bagaimanakah motivasi siswa dalam pembelajaran bahasa Inggris MAS Tahfizil Qur'an Dan MTS Hifzhil Qur'an Medan Sumatera Utara melalui sebuah metode belajar CTL?

\section{TUJUAN PENGABDIAN}

\subsection{Tujuan Umum Pengabdian Masyarakat}

Adapun tujuan umum pengabdian pada masyarakat ini adalah untuk meningkatkan motivasi pembelajaran bahasa Inggris dalam memahami tatabahasa 'direct and indirect speech' melalui sebuah metode belajar CTL kepada siswa kelas XII MAS Tahfizil Qur'an Dan kelas IX MTS Hifzhil Qur'an Medan Sumatera Utara.agar dapat menjadi bekal pemberi semangat untuk 
Syahron. et.al. Memotivasi Pembelajaran Bahasa Inggris Melalui Metode Belajar Ctl Di Mas Tahfizil Qur'an Dan Mts Hifzhil Qur'an Medan Sumatera Utara

persiapan mereka menghadapi ujian akhir tingkat nasional.

\subsection{Tujuan Khusus Pengabdian Masyarakat}

Tujuan khusus dari pengabdian masyarakat ini adalah memotivasi pemebelajaran bahasa Inggris agar bisa mengetahui bentuk, struktur dan perbedaan tatabahasa 'direct and indirect speech' melalui metode belajar CTL kepada siswa kelas XII MAS Tahfizil Qur'an Dan kelas IX MTS Hifzhil Qur'an Medan Sumatera Utara untuk mendukung kemampuan para siswa dalam menguasai bahasa Inggris sebagai bekal yang berguna tidak hanya untuk menghadapi ujian akhir nasional namun juga menghadapi seleksi penerimaan mahasiswa pergururan tinggi negeri.

Selain itu, tujuan khusus lainnya adalah untuk menemukan cara yang lebih efektif dan efisien untuk memotivasi pembelajaran bahasa Inggris dalam memahami tatabahasa 'direct and indirect speech' melalui metode belajar CTL oleh siswa MAS Tahfizil Qur'an Dan MTS Hifzhil Qur'an Medan Sumatera Utara sehingga kemampuan penguasaan bahasa Inggris mereka semakin meningkat.

\section{KERANGKA PENELITIAN}

\subsection{Pengertian Contextual Teaching and Learning (CTL)}

Contextual Teaching and Learning (CTL) adalah metode pengajaran yang membantu guru menghubungkan materi pelajaran dengan situasi dunia nyata dan memotivasi siswa untuk membuat hubungan antara pengetahuan dan penerapannya terhadap kehidupan mereka sebagai anggota keluarga, warga negara, siswa, dan pekerja (Trianto, 2008:17)

Contextual Teaching and Learning (CTL) juga didefinisikan sebagai salah satu metode pembelajaran yang memiliki hubungan dengan situasi alam dalam proses pembelajaran dimana kelas akan lebih atraktif dan bermakna. Hal itu terjadi ketika para siswa memiliki pemahaman tentang pengalaman tentang apa yang telah mereka pelajari (Jeanny,2013). Inti metode CTL adalah mengambil situasi fakta sebagai sumber belajar.

CTL adalah metode dalam proses belajar mengajar yang paling menarik bagi manusia. Berbeda dengan strategi lainnya, CTL memperoleh kemampuan siswa dalam memperoleh materi yang telah dipelajari dan menghubungkannya dengan situasi sebenarnya, sehingga bisa memotivasi siswa untuk menggunakan kemampuan mereka dalam kehidupan mereka (Sanjaya, 2008:255).

\subsection{Karakteristik Contextual Teaching and Learning (CTL)}

Contextual Teaching and Learning (CTL) adalah salah satu topik hangat dalam pendidikan.Ini adalah pendekatan instruksional yang didasarkan pada premis bahwa makna muncul dari hubungan antara konten dan konteksnya.Dalam hal ini, konteks memberi makna pada konten. Semakin luas konteks di mana siswa dapat membuat koneksi, semakin banyak konten makna yang akan mereka hadapi. Pendekatan tersebut menekankan penemuan makna sebagai ciri utama (Johnson, 2009:3)

\subsection{Komponen Contextual Teaching and Learning ( CTL)}

Contextual Teaching and Learning (CTL) memiliki beberapa komponen. Ada tujuh komponen dalam CTL, yaitu (1) Constructivism, (2) Inquiry, Questioning, (4) Learningcommunity, (5) Modeling, (6) Reflections, (7) AuthenticAssessment (Berns\& Erickson, 2001:33)

\subsection{Prinsip Contextual Teaching and Learning (CTL)}


Syahron. et.al. Memotivasi Pembelajaran Bahasa Inggris Melalui Metode Belajar Ctl Di Mas Tahfizil Qur'an Dan Mts Hifzhil Qur'an Medan Sumatera Utara

Serupa dengan pendekatan atau metode pengajaran lainnya, CTL juga memiliki beberapa prinsip yang berbeda.Johnson (2009:68) menyatakan bahwa CTL mencakup tiga prinsip tipikal, yaitu; (1) interdependence, (2) differentiation, and (3) self organization.

\section{METODE PENELITIAN}

Jenis metode penelitian yang digunakan pada penelitian ini adalah pendekatan sebuah metode penelitian kulaitatif deskriptif berupa penelitian lapangan. Dimana hasil data penelitian diperoleh oleh peneliti melalui sebuah praktek percobaan lapangan.

\section{PEMBAHASAN}

\subsection{Kegiatan Yang Telah Dilaksanakan}

\subsubsection{Tahap Test Awal}

Konsep dasar yang dijadikan pegangan dalam pengabdian ini ialah penentuan faktor - faktor penyebab kurang termotivasinya siswa dalam belajar bahasa Inggris yang terdapat dalam struktur bahasa Inggris di sekolah. Hal ini dilakukan dengan memberikan test awal (pre-test) sebelum menerapkan CTL, pretest akan diberikan kepada siswa. Hal itu dilakukan untuk mengetahui seberapa besar motivasi dan kemampuan siswa dalam menguasai tata bahasa 'direct and indirect speech'. Setelah memberikan pre-test, siswa akan diberi treatment tentang tata bahasa 'direct and indirect speech' dengan metode CTL untuk 4 kali kunjungan. Waktu yang dialokasikan untuk kegiatan kelas adalah 90 menit untuk setiap pertemuan.

\subsubsection{Tahap pelatihan Siswa}

Selanjutnya, hasil dari test awal tersebut dideskripsi dan diklasifikasi untuk selanjutnya tim membuat strategi cara memotivasi siswa yang lebih efektif sesuai dengan kebutuhan siswa dengan memberikan materi pembelajaran yang meliputi:

a. Materi Pertama: Peningkatan motivasi pembelajatran atau kemauan diri siswa/i untuk melakukan percakapan sehari-hari menggunakan bahasa Inggris yang difokuskan pada bidang kehidupan sehari - hari agar para peserta percaya diri mengikuti program pembelajaran melalui sebuah metode belajar CTL.

b. Materi Kedua: Peningkatan pemahaman siswa dalam menggunakan bahasa Inggris yang difokuskan pada bidang struktur kalimat langsung dan kalimat tidak langsung sebagai bentuk grammaragar para peserta berhasil lulus mengikuti ujian akhir nasional dan ujian masuk perguruan tinggi negeri.

c. Materi Ketiga: Peningkatan kemampuan siswa dalam menggunakan bahasa Inggris yang difokuskan pada bidang struktur kalimat langsung dan kalimat tidak langsung sebagai bentuk grammar agar para peserta berhasil lulus mengikuti ujian akhir nasional dan ujian masuk perguruan tinggi negeri.

Kegiatan pertama yang dilakukan pada tahap pelaksanaan pembelajaran adalah persiapan pelaksanaan pembelajaran. Pada sesi ini dilakukan penjelasan mengenai percakapan seharihari bahasa Inggris yang difokuskan pada bidang kehidupan sehari - hari. Kegiatan kedua adalah sesi pembelajaran yang menitikberatkan pada kemampuan siswa dalam dalam menggunakan bahasa Inggris yang difokuskan pada bidang struktur kalimat langsung dan kalimat tidak langsung sebagai bentuk grammar. Pemberian kemampuan ini dilakukan dengan teknik simulasi agar para siswa mendapatkan pengalaman langsung beserta pengayaan dari teman-temannya juga dari tim pengajar. Diharapkan para peserta pembelajaran dapat benar-benar 
Syahron. et.al. Memotivasi Pembelajaran Bahasa Inggris Melalui Metode Belajar Ctl Di Mas Tahfizil Qur'an Dan Mts Hifzhil Qur'an Medan Sumatera Utara

memahami materi ajar yang diberikan, mampu menerapkan materi yang diberikan selama pembelajaran pada kegiatan teknis melakukan percakapan sehari-hari dalam bahasa Inggris yang difokuskan pada bidang kehidupan sehari - hari dalam bentuk struktur kalimat langsung dan kalimat tidak langsung serta kemudian mengidentifikasi kesulitan-kesulitan jika ada untuk kemudian dipecahkan.

Dalam kegiatan pelatihan ini, pihak pengelola sekolah MAS Tahfizil Qur'an dan MTs Hifzhil Qur'an Medan Sumatera Utara juga turut berpartisipasi mmepersiapkan ruang, fasilitas dan mahasiswa yang akan mengikuti program pembelajaran bahasa Inggris. Evaluasi kegiatan dilakukan pada aspek pencapaian tujuan dan juga penyelenggaraan pembelajaran selama proses dan akhir pelatihan. Evaluasi selama proses belajar adalah evaluasi saat pelaksanaan pembelajaran yang meliputi keterlibatan serta kemampuan peserta pada setiap tahap pembelajaran.

Pada tahap akhir pembelajaran, para peserta diharapkan dapat melakukan kegiatan teknis melakukan percakapan sehari-hari menggunakan bahasa Inggris yang difokuskan pada kehidupan sehari hari. Evaluasi mengenai proses dan pencapaian tujuan pembelajaran dilakukan dengan menggunakan angket tanya jawab dan observasi.

Indikator keberhasilan proses pelatihan ini adalah, (1) lebih dari 90\% para siswa/i memahami struktur kalimat langsung dan kalimat tidak langsung dan mampu melakukan percakapan seharihari menggunakan bahasa Inggris yang difokuskan pada kehidupan yang nyata, (2) lebih dari $90 \%$ para siswa setelah tamat agar para peserta berhasil lulus mengikuti ujian masuk perguruan tinggi negeri.

Tim Pelaksana Pengabdian pada Masyarakat akan melakukan evaluasi dengan cara memeriksa hasil test pembelajaran dan mendengarkan kegiatan percakapan menggunakan bahasa Inggris yang difokuskan pada kehidupan yang nyata atau percakapan sehari - hari yang dilakukan oleh para siswa/iMAS Tahfizil

Qur'an dan MTsHifzhil Qur'an Medan Sumatera Utara. Keberlanjutan program setelah selesai kegiatan IbM dilaksanakan adalah pihak mitra atau kedua sekolah akan memasukkan materi pembelajaran bahasa Inggris dalam kurikulum sekolah.

\section{HASIL YANG DICAPAI}

\subsection{Hasil Yang Dicapai Dalam Pelatihan Pengabdian Masyarakat Memotivasi Pembelajaran Bahasa Inggris Melalui Metode Belajar CTL Di MAS Tahfizil Qur'an Medan Sumatera Utara}

Pelatihan pengabdian masyarakat Memotivasi Pembelajaran Bahasa Inggris Melalui Metode Belajar CTL Di MAS Tahfizil Qur'andanMTs Hifzhil Qur'an Sumatera Utara yang dilakukan pada dua lokasi tersebut dimana setiap lokasi terdapat 35 siswa setiap sekolah dan jumlah siswa yang hadir secara keseluruhan adalah sebanyak 70 orang. Dalam pelaksanaan pelatihan ini, kegiatan diawali dengan pemberian tahap pre test yang berisi soal tatabahasa atau grammar kalimat langsung dan kalimat tidak langsung dalam bahasa Inggris dalam bentuk pilihan berganda. Hal ini dilaukan dengan tujuan untuk melihat kemampuan para siswa sebelum dilakukan pelatihan yang nantinya akan dibandingkan dengan kemampuan siswa setelah selesai pelatihan. Dalam menyelesaikan Pre-test, para siswa diberikan waktu selama 45 menit untuk menyelesaikan tahapan Pretest ini.

Setelah selesai melakukan Pre-test, maka tahap selanjutnya adalah pelaksanaan tahap pelatihan. Tahap pelatihan dimulai dengan ceramah penyampaian materi oleh para penyampai materi. Selain penyampaian materi, penyuluh juga 
Syahron. et.al. Memotivasi Pembelajaran Bahasa Inggris Melalui Metode Belajar Ctl Di Mas Tahfizil Qur'an Dan Mts Hifzhil Qur'an Medan Sumatera Utara

meminta para siswa untuk mengikuti penereapan metode CTL secara langsung. Hasil yang diperoleh secara langsung adalah antusiasme para siswa dalam metode CTL yang belum pernah mereka ketahui sebelumnya. Dengan metode tersebut, mereka dapat merasakan perubahan yang signifikan yakni termotivasinya siswa dalam belajar grammar secara sederhana dengan sebuah kelompok kerja kecil yang bisa saling membantu satu sama lain. Siswa merasa lebih bersemangat untuk mempelajari struktur bahasa Inggris dengan rekan kelompoknya dengan panduan dari para pelatih.

Setelah ceramah penyampaian materi yang dilakukan oleh pelatih pertama, pelatihan dilanjutkan dengan penyampaian materi oleh pelatih kedua dan ketiga secara kolaboratif. Pelatih kedua dan ketiga saling berganti posisi untuk menyampaikan dan mengawasi jalannya pelatihan yang disertai dengan penerapan metode pula. Selain tiga pemateri ada juga seorang mahasiswa yang turut berpartisipasi dalam pelatihan untuk memberikan bantuan demi lancarnya pelatihan tersebut. Hasil yang diperoleh adalah tingkat motivasi lebih tinggi dan keingintahuan menyeluruh siswa tentang materi yang diberikan dikarenakan penerapan metode belajar struktur bahasa yang diberikan dilakukan secara berkesinambungan. Peningkatan pemahaman dengan pembuktian jawaban yang benar dalam menjawab soal-soal semakin tinggi.

Setelah penyampaian materi dilakukan maka tahapan terakhir adalah pemberian Post-test sebagai tolak ukur pembanding untuk melihat hasil yang diperoleh sebelum dan setelah dilakukannya pelatihan. Post-test yang diberikan berisi soal-soal grammar kalimat langsung dan kalimat tidak langsung (Reported Speech) sebanyak 20 soal dalam bentuk pilihan berganda. Waktu yang diberikan untuk menjawab Post-test adalah selama 45 menit. Hasil yang dicapai adalah peningkatan hasil Post-test yang signifikan dibandingkan dengan Pre-test. Hasil yang dicapai adalah peningkatan hasil Post-test sebanyak $73 \%$ dari para siswa dapat menjawab pertanyaan dengan hasil yang memuaskan. Oleh karena itu, dapat dikatakan bahwa pelatihan ini telah memberikan manfaat yang baik kepada para siswa MAS Tahfizil Qur'an Medan Sumatera Utara secara signifikan.

\subsection{Hasil Yang Dicapai Dalam Pelatihan Pengabdian Masyarakat Memotivasi Pembelajaran Bahasa Inggris Melalui Metode Belajar CTL Di MTs Hifzhil Qur'an Medan Sumatera Utara}

Pelatihan pengabdian masyarakat Memotivasi Pembelajaran Bahasa Inggris Melalui Metode Belajar CTL Di MTs Hifzhil Qur'an Sumatera Utara yang dilakukan pada lokasi kedua ini terdapat 35 siswa. Dalam pelaksanaan pelatihan ini, kegiatan diawali dengan pemberian tahap pre test yang berisi soal tatabahasa atau grammar kalimat langsung dan kalimat tidak langsung dalam bahasa Inggris dalam bentuk pilihan berganda. Hal ini dilaukan dengan tujuan untuk melihat kemampuan para siswa sebelum dilakukan pelatihan yang nantinya akan dibandingkan dengan kemampuan siswa setelah selesai pelatihan. Dalam menyelesaikan Pre-test, para siswa diberikan waktu selama 45 menit untuk menyelesaikan tahapan Pre-test ini.

Setelah selesai melakukan Pre-test, maka tahap selanjutnya adalah pelaksanaan tahap pelatihan. Tahap pelatihan dimulai dengan ceramah penyampaian materi oleh para penyampai materi. Selain penyampaian materi, penyuluh juga meminta para siswa untuk mengikuti penereapan metode CTL secara langsung. Hasil yang diperoleh secara langsung adalah antusiasme para siswa dalam metode CTL yang belum pernah mereka ketahui sebelumnya. Dengan metode tersebut, mereka dapat merasakan perubahan yang signifikan yakni termotivasinya siswa dalam belajar grammar secara sederhana dengan sebuah kelompok kerja kecil yang bisa saling 
Syahron. et.al. Memotivasi Pembelajaran Bahasa Inggris Melalui Metode Belajar Ctl Di Mas Tahfizil Qur'an Dan Mts Hifzhil Qur'an Medan Sumatera Utara

membantu satu sama lain. Siswa merasa lebih bersemangat untuk mempelajari struktur bahasa Inggris dengan rekan kelompoknya dengan panduan dari para pelatih.

Setelah ceramah penyampaian materi yang dilakukan oleh pelatih pertama, pelatihan dilanjutkan dengan penyampaian materi oleh pelatih kedua dan ketiga secara kolaboratif. Pelatih kedua dan ketiga saling berganti posisi untuk menyampaikan dan mengawasi jalannya pelatihan yang disertai dengan penerapan metode pula. Selain tiga pemateri ada juga seorang mahasiswa yang turut berpartisipasi dalam pelatihan untuk memberikan bantuan demi lancarnya pelatihan tersebut. Hasil yang diperoleh adalah tingkat motivasi lebih tinggi dan keingintahuan menyeluruh siswa tentang materi yang diberikan dikarenakan penerapan metode belajar struktur bahasa yang diberikan dilakukan secara berulangulang dengan berkelompok. Peningkatan pemahaman dengan pembuktian jawaban yang benar dalam menjawab soal-soal semakin tinggi.

Setelah penyampaian materi dilakukan maka tahapan terakhir adalah pemberian Post-test sebagai tolak ukur pembanding untuk melihat hasil yang diperoleh sebelum dan setelah dilakukannya pelatihan. Post-test yang diberikan berisi soal-soal grammar kalimat langsung dan kalimat tidak langsung (Reported Speech) sebanyak 20 soal dalam bentuk pilihan berganda. Waktu yang diberikan untuk menjawab Post-test adalah selama 45 menit. Hasil yang dicapai adalah peningkatan hasil Post-test yang signifikan dibandingkan dengan Pre-test. Hasil yang dicapai adalah peningkatan hasil Post-test sebanyak $71 \%$ dari para siswa dapat menjawab pertanyaan dengan hasil yang memuaskan. Oleh karena itu, dapat dikatakan bahwa pelatihan ini telah memberikan manfaat yang baik kepada para siswa MTs Hifzhil Qur'anMedan Sumatera Utara secara signifikan.

\section{SIMPULAN}

Kesimpulan yang diperoleh setelah dilakukannya pengabdian masyarakat dalam bentuk pelatihan Memotivasi Pembelajaran Bahasa Inggris Melalui Metode Belajar CTL di MAS Tahfizil Qur'andan MTs Hifzhil Qur'an Sumatera Utara adalah sebagai berikut:

1) Pelatihan Memotivasi Pembelajaran Bahasa Inggris Melalui Metode Belajar CTL Di MAS Tahfizil Qur'andanMTs Hifzhil Qur'an Sumatera Utara telah dilakukan dan hasilnya sangat memuaskan.

2) Metode belajar Contextual Teaching and Learning (CTL) yang telah di terapkan kepada siswa MAS Tahfizil Qur'andanMTs Hifzhil Qur'an Sumatera Utara memberikan hasil yang signifikan dimana para siswa termotivasi dan dapat mengikuti metode tersebut sehingga pemahaman terhadap struktur grammar kalimat langsung dan kalimat tidak langsung dipahami secara menyeluruh dalam waktu yang relative singkat.

3) Kemampuan siswa dalam memahami grammar setelah diajarkan dengan menggunakan metode belajar CTL meningkat dalam persentase $75 \%$ hasil memuaskan di MAS Tahfizil Qur'an dan $70 \%$ hasil memuaskan di MTs Hifzhil Qur'an Sumatera Utara.

4) Antusiasme dari para siswa terhadap metode yang mereka anggap baru ini tergolong baru.

\section{UCAPAN TERIMA KASIH}

Kegiatan pengabdian masyarakat yang telah dilaksanakan telah dapat diselesaikan dengan dan didapat hasil yang diharapkan dapat diadopsi oleh masyarakat. Dalam pelaksanaan kegiatan ini, tim peneliti banyak mendapat bantuan dari bebagai kalangan, sehingga kegiatan pengabdian ini dapat terlaksana. Sehubungan dengan hal tersebut, tim peneliti mengucapkan terima 
Syahron. et.al. Memotivasi Pembelajaran Bahasa Inggris Melalui Metode Belajar Ctl Di Mas Tahfizil Qur'an Dan Mts Hifzhil Qur'an Medan Sumatera Utara

kasih kepada LPPM USU yang telah membiayai kegiatan ini.

\section{DAFTAR PUSTAKA}

Allice.http://www.studyandexam.com/timepronoun-change-in-indirectspeech.html. Accessed on December $1^{\text {st }} 2012$.

Bynes.http://www.englishlesson.com/4117changing-direct-speech-to-indirectspeech-2-primary-english-grammarmexus.html.Accessed on March $10^{\text {th }}$ 2013.

Berns, R \& Erickson, P. 2001. Contextual Teaching and Learning, (London: The Highlight). p. 23.

Blanchard, Alan. Contextual Teaching and Learning; Horizons Electronic Lesson Plans Resource, http:// www.horizonshelpr.org/contextual/c ontextual.htm. Accessed on April $2^{\text {nd }}$ 2013.

Carmina.http://www.grammaring.com/thedifference-between-direct-andindirect-speech. Accessed on March $10^{\text {th }} 2013$.

Hotben, D. 2003.Intisari Tata Bahasa Inggris Kontemporer,( Jakarta: Kesaint Blanc) p.486

Ifraj, S. 2002.Contextual Teaching and Learning Practice In family and Consumers Sciences Curriculum, (Georgio: Columbia Middle School), P.14

Jeanny.www.texascollaborative.org/whtisCTL. html. Accessed on April 30 2013

Johnson. 2009.Contextual Teaching and Learning:Menjadikan Kegiatan Belajar-Mengajar Mengasyikkan dan
Bermakna, (Bandung: Mizan Learning Center), P. 3.

Manhuja, English Grammar (online) $h t t p: / / w w w . a t h a b a s c a u . C a / c$ ourse/engl/155/support/

indirect.Htm. Accessed on $13^{\text {rd }}$ September 2012.

Manjhusha,

EnglishGrammar,http://www.athaba scau.ca/course/engl/155/support/dire ct and indirect speech, Accessed on February $28^{\text {th }}, 2013$.

Murphy. 1985.English Grammar in Use, with Answer - Intermediate (London: Cambridge University Press), p. 92.

Nurhadi, dkk. 2004.Pembelajaran Kontextual (Contextual Teaching and learning / CTL) dan Penerapannya dalam $K B K$ (Malang: Universitas Negeri Malang), p.12.

Sanjaya, W. 2008.Strategi Pembelajaran Berorientasi Standar Proses Pendidikan, (Jakarta: Kencana Prenada Media Group), p.255.

Sanjaya, W. 2008. Pembelajaran Dalam Implementasi Kurikulum Berbasis Kompetensi, (Jakarta: Kencana), p.109.

Schramper, A. 1992.Fundamental of English Grammar. $2^{\text {nd }}$ Edition, (New Jersey: Prentice Hall), p. 366

Trianto.2008. Mendesain Pembelajaran Kontekstual di Kelas (Jakarta: Pustaka Publisher). p.17

Yani, A. 2005.A Study on the Implementation of CTL for teaching EFL at SMAN 1 Malang.Thesis of English Department of State University of Malang. (Malang: Unpublished), p.18. 